\title{
IN VITRO ELIMINATION OF DAHLIA MOSAIC VIRUS BY USING MERISTEM CULTURE, ELECTROTHERAPY AND CHEMOTHERAPY
}

\author{
Z. A. A. Nerway ${ }^{1}$ \\ M. M.S. Duhoky ${ }^{2}$ \\ N. A. Kassim ${ }^{3}$
}

${ }^{1}$ Lecturer, Dept. Plant Protec., Coll. Agric. Engineer. Sci., University of Duhok, Iraq.

${ }^{2}$ Prof., Dean of University of Iraq.

${ }^{3}$ Prof., Dept. Plant Protec., Coll. Agric. and Forestry, University of Mosul, Iraq.

zulaykha_a@yahoo.com

\section{ABSTRACT}

This study was conducted to investigate the effect of different in vitro techniques on elimination of dahlia mosaic virus. Meristems of Dahlia mosaic virus (DMV) infected dahlias, with 0.2-0.3 mm in length, were cultured on Murashige and Skoog (MS) medium. Based on DAS-ELISA, 100\% of the survived plantlets by meristem culture were virus-free. DMV infected stem segments with two axillary buds were treated at three different levels of electric currents $(15,25$ and $35 \mathrm{~mA})$ and two time courses $(10$ and $20 \mathrm{~min})$ in an electrophoresis tank and cultured on MS medium. The treatment of $35 \mathrm{~mA}$ for $20 \mathrm{~min}$ was the best for viral elimination from diseased dahlias by $85 \%$ followed by $25 \mathrm{~mA}$ for $20 \mathrm{~min}$ by $70 \%$. Acyclovir and salicylic acid were the antivirals were used to eliminate DMV from the infected dahlias. For chemotherapy, nodes were cultured on MS media supplemented with antivirals at $0,10,20,30,40$ and $50 \mathrm{mg} / \mathrm{l}$ for 20 and 30 days. The highest concentration of acyclovir (50 $\mathrm{mg} / \mathrm{l})$ for 30 days were the best treatments as its highest effectiveness on elimination ability $(\mathbf{9 0 . 6 7 \%})$ but gave only $49 \%$ for plantlet survival. Whereas $40 \mathrm{mg} / \mathrm{l}$ acyclovir for 30 days gave elimination ability $(80 \%)$ and plantlet survival $(89.67 \%)$. The therapy containing salicylic acid at $40 \mathrm{mg} / \mathrm{l}$ for 30 days was the best as its highest effectiveness on DMV elimination ability (100\%). But the concentration of salicylic acid at $30 \mathrm{mg} / \mathrm{l}$ for 30 days was the best treatment (chemotherapy efficiency $=49.21)$ as well as DMV elimination ability $(\mathbf{7 5 . 3 3 \%})$ and plant survival (65.33\%). The in vitro developed dahlia plantlets were tested for DMV-freeness using DAS-ELISA. The using therapies (electrotherapy and chemotherapy) can play a good role in virus elimination because they need the minimum period of time to regenerate fully developed healthy plants as long as 2-3 months.

Keywords: DMV eradication, meristematic tissue, electric currents, chemicals.

نيَروةتي وآخرون

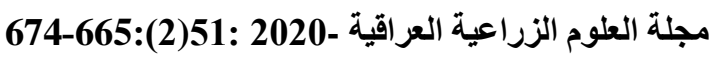

ازالة فايروس موزائيك الداليا بتقانات زراعة الأنسجة بواسطة زراعة المرستيم القمي، المعالجة الكهريائية و الكيمياوية

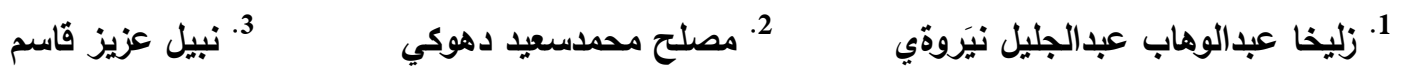

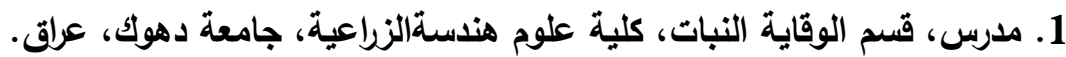





المستخلص

وقد أجريت الدراسة لمعرفة تأثير تقنيات مختلفة في المختبر على القضاء على فايروس موزاييك الداليا. تم تريبت مرستيمات النباتات الداليا المصابة ب






خزان الكهريائي وزرعت في وسط الزرعي MS. وكانت المعاملة بقوة mA 35 لددة عشرين دقيقة هي الأفضل في ازالة الفايروس من نبيتات الداليا وينسبة ازالة 85\%، ثم تلتها المعاملة بقوة mA 25 لمدة 20 دقيقة بنسبة ازالة 70\%. استعمل مركبي اسايكلوفير وحامض السالسيلك لإزالة

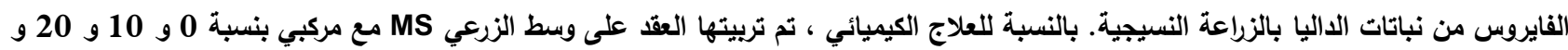

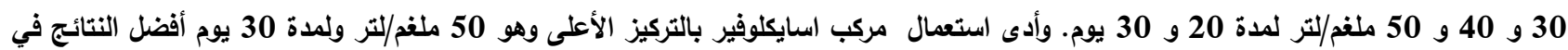
ازالة الفايروس ، وينسبة 90.67\% ولكن كانت نسبة بقاء النبيتات منذفضة وهي 49\%.

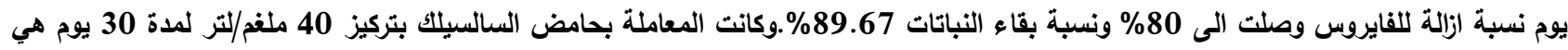

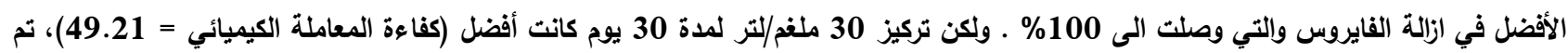

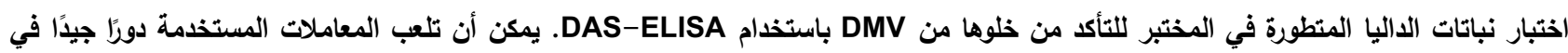


الكلمات المفتاحية: استئصال DMV، نسيج مريستيمي، التيارات الكهريائية، المواد الكيمياوية.

*Received:16/6/2019, Accepted:12/9/2019 


\section{INTRODUCTION}

Dahlia (Family Asteraceae) is an important ornamental crop which is important for its flowers and widely grown in several countries. Several viruses are known to infect dahlia. Dahlia mosaic virus (DMV) is the distinct caulimovirus that found to be associated with dahlia mosaic diseases (8) that considered being the most important and prevalent plant pathogenic virus that has economic impact on dahlia flower production (30). DMV virion is icosohedral particle, $48-50 \mathrm{~nm}$ in diameter, consists of double stranded DNA (dsDNA) genome with a size about 7 killobase pairs (42). It is well established that the viral diseases in different crops lead quantitative and qualitative losses of the flowers a plant produced $(30,35)$. Virus control is very difficult because virus replication inhibitors have shown to be having toxic effects on the host plant cell. This is the main reason for using of micro-propagation techniques to eliminate virus $(9,40)$. Tip meristem culture is the most commonly used method to obtain plants free of virus (36). Morel and Martin (22) first demonstrated the elimination of viruses from dahlia using meristem culture. Since the use of meristem culture to obtain virus-free ornamental plants has been widely used by numerous groups of researchers (38). Electrotherapy has been applied by using electric currents on infected plant tissues for virus elimination from any part of the infected plants especially the vegetative propagules. The chemicals used in chemotherapy are antivirals incorporated in to culture media with a known capability to stop virus replication and their natural and synthetic varieties are tested for their potential to eliminate DNA and RNA plant viruses (35). The requirements of a useful antiviral chemical is its abilities to inhibit multiplication and spread of the virus; be selective enough not to harm the host plant; have broad-spectrum activities against a number of viral diseases; move systemically in the host; and have not harmful effects on the environment. Sharma et al. (37) studied the effect of acyclovir in vitro that was one of the best chemicals that inhibit virus in the infected plants. Exogenous salicylic acid application induced antioxidant systems to reduce oxidative stresses caused by pathogen infection $(41,45)$ especially viruses (14). Tian et al. (43) found that salicylic acid inhibits the replication of plant viruses. This study was conducted to evaluate the effect of meristem tip, different levels of electric currents and varying concentration levels of antivirals (acyclovir and salicylic acid) in the elimination of Dahlia mosaic virus (DMV) from infected dahlias.

\section{MATERIALS AND METHODS}

In spring of 2016 and 2017, young leaf samples of symptomatic dahlia plants (mosaic, systemic vein clearing, necrotic spots, stunting and malformation) collected from various gardens and nurseries of Duhok governorate/ Iraq. The collected leaves were used for virus isolation. The developed plants from cultured dahlia seeds with four fully expanded leaves were inoculated mechanically with virus isolated.

Diagnosis of DMV: The presence of DMV was detected in infected dahlia leaves using double antibody sandwich (DAS)-ELISA. The DMV antiserum kit was requested from SEDIAG Company, France. The diagnosis of the virus performed according to the manual instructions of kit.

\section{DMV elimination}

Meristem culture: Dahlia shoots that contain 3-5 axillary buds were collected from the greenhouse grown dahlias infected with DMV. The excised shoots were kept under running tap water before sterilization. The binocular microscope was surface sterilized by $70 \%$ ethanol. Forceps and scalpels were sterilized on flame burner. The shoot disinfestations were done by using $1 \% \mathrm{HgCl}_{2}$ and 2 drops of Tween-20 and shaking for $5 \mathrm{~min}$, in a laminar airflow cabinet. The treated shoots were washed with sterilized distilled water three times, 5 minutes for each washing. The leaves protecting the meristem were removed and the meristem was excised with $0.2-0.3 \mathrm{~mm}$ length under the microscope. The excised meristem contained meristem tip with one or two leaf primordia (Fig. 1). The explants were inoculated in glass jars containing MS medium supplemented with $0.5 \mathrm{mg} / \mathrm{l} \mathrm{IAA}$ and 0.25 $\mathrm{mg} / \mathrm{l} \mathrm{GA}$. The developed meristems, after 4 weeks of inoculation, were subcultured into a new media with the same composition. The plantlets when reached to an average length of 
$5 \mathrm{~mm}$ with few leaves were subcultured into multiplication medium supplemented with 0.0 , $0.5,1.0,1.5$ and $2.0 \mathrm{mg} / \mathrm{l} \mathrm{BA}$ and $0.25 \mathrm{mg} / \mathrm{l}$ $\mathrm{GA}_{3}$. The plantlets with 3-4 cm height were transferred into a full and half strength media containing different concentration of IBA $(0.0$, $0.5,1.0,1.5$ and $2.0 \mathrm{mg} / \mathrm{l})$ to induce rooting $(12,27)$. Well developed plantlets with root systems were taken out from the controlled environment. The plantlets were washed thoroughly under running tap water to remove the medium. Then, the plantlets were transplanted into a sterilized peat-moss in addition of benlite $(2 \mathrm{~g} / \mathrm{l})$ and kept at room temperature for 10 days to contact normal temperature. After hardening-off period, the developed plants transplanted into a tightly controlled atmosphere of the greenhouse (28).

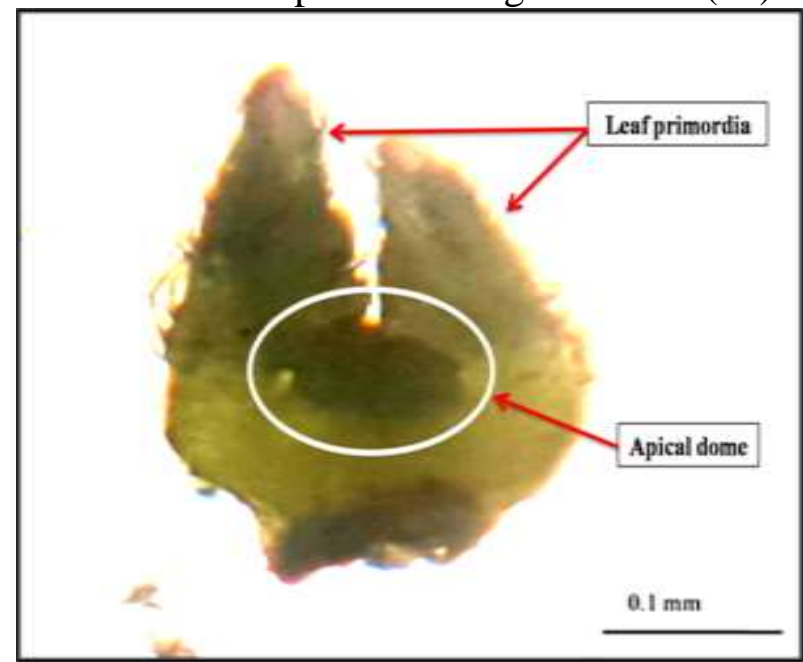

Figure 1. The excised meristem tip from shoot tip of dahlia plant containing apical dome with two leaf primordia under light microscope. $X=40 \%$. Bar $=0.1 \mathrm{~mm}$

\section{Electrotherapy}

The most vigorous stems of DMV infected dahlias were selected and used for electrotherapy. Stem segments with two axillary buds were treated at three different levels of electric currents $(15,25$ and $35 \mathrm{~mA})$ and two time courses (10 and $20 \mathrm{~min})$ in an electrophoresis tank (20). Electric currents were supplied by an electrophoresis power supply. The treated axillary buds were removed from stem segments and cultured on MS medium supplemented with BA $(2 \mathrm{mg} / \mathrm{l})$ and $\mathrm{GA}_{3}(0.25 \mathrm{mg} / \mathrm{l})$, after sterilizing with $0.1 \%$ mercuric chloride for $5 \mathrm{~min}$. Effects of in vitro electrotherapy treatments on virus elimination and regeneration of plantlets were studied using ten replicates. Symptomatology test was used for viral presence in the developed explants. Efficiency of the therapy was estimated according to the following formula: efficiency of therapy $=$ virus elimination percent $\times$ percent of plantlet regeneration (32).

Chemotherapy: Stem cuttings with one or two leaf nodes cut from DMV infected plants and cultured on MS medium containing two antivirals including acyclovir and salicylic acid $(23,33)$. Acyclovir and salicylic acid were added at $0,10,20,30,40$ and $50 \mathrm{mg} / \mathrm{l}$. The chemicals were applied into MS medium just after autoclaving. Shoots were cultivated on these types of media for 20 and 30 days and transferred into the medium containing plant growth regulators without antivirals. Well developed explants tested for viral presence using symptomatology. Percentage of survived cuttings counted for each concentration after 20 days of treatment $(6,47)$. Efficiency of the therapy was estimated according to the formula mentioned in electrotherapy. The in vitro grown explants were incubated at $25 \pm$ $2^{\circ} \mathrm{C}$ under $16 / 8 \mathrm{hrs}$ (light/dark) photoperiod provided by fluorescent tubes at 1000 lux light intensity in growth chamber. Treatments were consisted of ten glass jars with three replicates and the factorial experiment within Complete Randomized Design (CRD) was used. All data were statistically analyzed with computer using SAS program (34). The difference s between various treatment means were tested with Duncan Multiple Range test at 5\% level.

\section{RESULTS AND DISCUSSION Diagnosis of DMV Using DAS-ELISA}

Positive reactions were observed in diagnosis of DMV in infected dahlia leaves and tubers by using DAS-ELISA that was characterized by yellow color as a response of the specific antigen (DMV) to its specific antibody. The colorless columns show the negative reaction that indicated the absence of the virus particles as well as viral infection in the leaves and tubers of the symptomless plants. The result was agreed with Nerway et al. (29).

\section{DMV elimination}

Meristem Culture: The cultured dahlia meristems with $0.2-0.3 \mathrm{~mm}$ in length containing apical dome with two leaf primordia on MS medium succeeded in survival with a percentage of $50 \%$ and 
developed entire plant parts. The inoculated meristems showed good response of development at initiation stage after two subcultures. Table 1 shows in vitro growth patterns of $D$. pinnata taken after four weeks of culture. The shoots number and the shoots height were positively correlated with each other where the value of highest mean was recorded in MS medium containing $2.0 \mathrm{mg} / \mathrm{l}$ BA and $0.25 \mathrm{mg} / \mathrm{l} \mathrm{GA}_{3}$ (shoots number: 3.14, shoots height: $5.58 \mathrm{~cm})$. The lowest shoots number and the shoots height were recorded in control treatment $(1.28$ and $2.5 \mathrm{~cm})$.

Table 1. Effects of BA concentrations on multiplication of dahlia meristems.

\begin{tabular}{|ccc|}
\hline BA+GA $(\mathrm{mg} / \mathrm{l})$ & $\begin{array}{c}\text { Shoot Height } \\
(\mathrm{cm})\end{array}$ & $\begin{array}{c}\text { Shoot } \\
\text { Number }\end{array}$ \\
\hline $\mathbf{0 . 0}+0.25$ & $2.50 \mathrm{e}$ & $1.28 \mathrm{~b}$ \\
$($ Control $)$ & $3.14 \mathrm{~d}$ & $1.42 \mathrm{~b}$ \\
$0.5+0.25$ & $3.92 \mathrm{c}$ & $2.10 \mathrm{~b}$ \\
$1.0+0.25$ & $4.78 \mathrm{~b}$ & $2.16 \mathrm{~b}$ \\
$1.5+0.25$ & $5.58 \mathrm{a}$ & $3.14 \mathrm{a}$ \\
\hline $2.0+0.25$ & &
\end{tabular}

* Means within a column, row and their interactions followed with the same letters are not significantly different from each other according to Duncan's multiple range tests at $5 \%$ level.

After analyzing the data, the effect of IBA on rooting stage of multiplied dahlia shoots is presented in table 2 . The results shows that the cultured dahlia shoots responded positively to IBA supply to MS media by root development and increasing the roots number and roots length by increasing IBA concentration to a specific. The mean of media strength shows that roots number and roots length of dahlia explants increased significantly in the full media strength $(3.14$ and $4.86 \mathrm{~cm})$ compared to half media strength $(2.46$ and $4.03 \mathrm{~cm})$. On the other hand, the mean effect of IBA shows that the lowest and the highest roots number were recorded in MS media supplemented with 0.0 and $1.0 \mathrm{mg} / \mathrm{l} \mathrm{IBA}$, respectively (1.46 and 3.88) while the lowest and the highest roots length were recorded in the media containing 0.0 and $1.5 \mathrm{mg} / \mathrm{l} \mathrm{IBA}(0.75 \mathrm{~cm}$ and $9.00 \mathrm{~cm}$ ).

Table 2. effect of IBA concentrations, in full and half strength MS media, on rooting of dahlia shoots.

\begin{tabular}{|c|c|c|c|c|c|c|}
\hline \multirow{2}{*}{ IBA (Mg/l) } & \multicolumn{3}{|c|}{$\begin{array}{l}\text { Roots Number } \\
\text { Media Strength }\end{array}$} & \multicolumn{3}{|c|}{$\begin{array}{l}\text { Roots Length }(\mathrm{cm}) \\
\text { Media Strength }\end{array}$} \\
\hline & $\begin{array}{c}\text { Half } \\
\text { Strength }\end{array}$ & $\begin{array}{c}\text { Full } \\
\text { Strength }\end{array}$ & $\begin{array}{c}\text { Half } \\
\text { Strength }\end{array}$ & $\begin{array}{c}\text { Full } \\
\text { Strength }\end{array}$ & $\begin{array}{c}\text { Half } \\
\text { Strength }\end{array}$ & $\begin{array}{c}\text { Full } \\
\text { Strength }\end{array}$ \\
\hline 0.0 & $1.33 \mathrm{c}$ & $1.60 \mathrm{~d}$ & $1.46 \mathrm{~d}$ & $0.67 \mathrm{e}$ & $0.83 \mathrm{~d}$ & $0.75 \mathrm{~d}$ \\
\hline 0.5 & $1.83 \mathrm{c}$ & $2.70 \mathrm{c}$ & $2.26 \mathrm{c}$ & $2.33 \mathrm{~d}$ & $4.00 \mathrm{c}$ & $3.16 \mathrm{c}$ \\
\hline 1.0 & $4.17 \mathrm{a}$ & $3.60 \mathrm{~b}$ & $3.88 \mathrm{a}$ & $4.67 \mathrm{~b}$ & $5.00 \mathrm{~b}$ & $4.83 \mathrm{~b}$ \\
\hline 1.5 & $3.17 \mathrm{~b}$ & $5.80 \mathrm{a}$ & $2.99 \mathrm{~b}$ & $8.67 \mathrm{a}$ & $9.33 \mathrm{a}$ & $9.00 \mathrm{a}$ \\
\hline 2.0 & $1.83 \mathrm{c}$ & $2.00 \mathrm{~d}$ & $1.91 \mathrm{~d}$ & $3.83 \mathrm{c}$ & $5.17 \mathrm{~b}$ & $4.50 \mathrm{~b}$ \\
\hline $\begin{array}{l}\text { Mean of media } \\
\text { strength }\end{array}$ & $2.46 \mathrm{~b}$ & $3.14 \mathrm{a}$ & & $4.03 \mathrm{~b}$ & $4.86 \mathrm{a}$ & \\
\hline
\end{tabular}

* Means within a column, row and their interactions followed with the same letters are not significantly different from each other according to Duncan's multiple range tests at $5 \%$ level.

The required time for developing the meristem explants to become rooted plantlets was as long as seven months. The rooted plantlets were successfully acclimatized in sterilized peat-moss with a survival rate of about $95 \%$. The developed plantlets were tested for DMVfreeness using DAS-ELISA. Moreover, the percentage of the virus freeness in regenerated plantlets was $100 \%$. Several techniques were evaluated for the ability to eliminate viruses from infected plants. Effects of meristem culture and electrotherapy were studied comparatively by Pazhohandeh et al. (32) indicating that the efficiency of each technique is dependent upon the cultivar-virus system and the intensity of the virus eradication treatment. After 10-20 days of meristems incubation, they were checked for their response to in vitro culture by gradual increasing in size and color change. The observation showed that the color of the grown meristems changed to green due to chlorophyll development. Disappearance of green color indicated the absence of chlorophyll development. Addition of growth regulators to MS medium plays an important role in shoot growth (9). Mehmood et al. (18) found that Plantlets developed in M.S media supplemented with $0.25 \mathrm{mg} / 1$ of $\mathrm{GA}_{3}$ produce maximum plant height, more number of nodes, reduced no. of days to root initiation and took less number of days to transferable height of 
the plant. Different combinations of $\mathrm{GA}_{3}$ and IAA within MS medium influenced in vitro shoot regeneration of meristem tip culture. This combination showed the best result for tip meristem development and shoot length improvement (6). Ibrahim and Daraj (2015) found that $2.0 \mathrm{mg} / \mathrm{l} \mathrm{BA}$ gave the highest significant response to shoot formation. The inclusion of auxins, like IBA, in culture medium has a positive effect on in vitro rooting of the shoots (39). Depending on the results, DMV could not introduce meristem with $0.2-0.3 \mathrm{~mm}$ height. Similar results have been noticed by Sedivá et al. (38) who eradicated DMV from infected plants by meristem-tip culture. Hull (11) reported that $0.2-0.3 \mathrm{~mm}$ meristem-tips with two leaf primordia were used for virus elimination. He reported that if the taken tissues include slightly expanded leaf primordia, the survival and growth of meristems would be greatly improved but at the same time increased the chance of virus entrance. Meristem culture provides an economical and reproducible method for producing virus-free plants. As meristem-tips are free from pathogens, virus eradication and regeneration of virus-free plants are possible through this technique. The efficiency of virus elimination will be different based on the virus and its host genotype (19). The principle of this technique depends on that many viruses are unable to infect the meristematic cells of the growing points of the plants. It remains still unclear that why the meristem has no virus, so there are several suggestions that may responsible of high protection against viruses. In meristematic cells, high metabolic activity and chromosome replication during mitosis may inhibit virus multiplication through interference with the metabolism of viral nucleic acid, so the virus may lose its ability to replicate (25). Meristematic tissues have the highest auxin concentration than other plant tissues. It has been suggested that auxin may inhibit the multiplication of the virus (10). Vascular tissue is a supporting element for rapid dissemination of viruses. Because of the absence of differentiated cells, the viruses that infect plant systemically have no ability to enter the meristematic tissues. Gene silencing, the process that is very active in meristematic tissues, is a mechanism that acts to defense the plant against viruses. This phenomenon may act as a restrict mechanism to inhibit the virus multiplication $(1,11)$. In general, the small size of the meristem increases the chance of virus elimination while the larger sizes increase the survival chances $(15,21)$. Meristems smaller than $0.2 \mathrm{~mm}$ have no ability to survive and those larger than $0.7 \mathrm{~mm}$ produce plants carrying virus (1). Tip-meristems larger than $0.5 \mathrm{~mm}$ were used in combination with some therapies such as electrotherapy (17).

\section{Electrotherapy}

Plants were regenerated successfully from all electrotherapy treatments. The treatment of 35 $\mathrm{mA}$ for $20 \mathrm{~min}$ was generally the most effective among the treatments in elimination of DMV at $85 \%$ and then $25 \mathrm{~mA}$ for $20 \mathrm{~min}$ at $70 \%$. The treatments of $15 \mathrm{~mA}$ for 10 and 20 min had no effect on virus elimination (Tab. 3). Regenerated control plantlets without electrotherapy treatment were positive for DMV (Tab. 3). Depending on the formula (Efficiency of therapy $=$ virus elimination percent $\times$ plantlet regeneration percent/ 100), the efficiency of electrotherapy was estimated (32). The treatments of $35 \mathrm{~mA}$ for 20 and 10 min were the most efficient $(55.25 \%$ and $52.50 \%$ ), respectively, among the treatments in regenerating the in vitro cultured dahlias and also in eradicating of DMV. The required time for developing the treated explants to become rooted plantlets was as long as 2-3 months. 
Table 3. Effects of electric currents in period of time on DMV elimination and survival of dahlia plantlets.

\begin{tabular}{|c|c|c|c|c|}
\hline \multicolumn{2}{|c|}{ Electrotherapy } & \multirow{2}{*}{$\begin{array}{c}\text { Plantlet } \\
\text { Survival } \\
(\%)\end{array}$} & \multirow{2}{*}{ 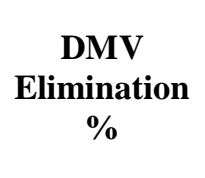 } & \multirow[b]{2}{*}{$\begin{array}{c}\text { Electrotherapy } \\
\text { Efficiency } \\
\%\end{array}$} \\
\hline $\begin{array}{c}\text { Electric } \\
\text { Currents } \\
(\mathbf{m A})\end{array}$ & $\begin{array}{l}\text { Period } \\
(\min )\end{array}$ & & & \\
\hline 0.0 & - & $100 \mathrm{a}$ & $0.0 \mathrm{e}$ & $0.0 \mathrm{e}$ \\
\hline \multirow{2}{*}{15} & 10 & $90.0 \mathrm{~b}$ & $0.0 \mathrm{e}$ & $0.0 \mathrm{e}$ \\
\hline & 20 & 88.0 b & $0.0 \mathrm{e}$ & $0.0 \mathrm{e}$ \\
\hline \multirow{2}{*}{25} & 10 & 85.0 b & $35.0 \mathrm{~d}$ & $29.75 d$ \\
\hline & 20 & $75.0 \mathrm{c}$ & $70.0 \mathrm{~b}$ & $52.50 \mathrm{~b}$ \\
\hline \multirow{2}{*}{35} & 10 & $70.0 \mathrm{~d}$ & $60.0 \mathrm{c}$ & $42.0 \mathrm{c}$ \\
\hline & 20 & $65.0 \mathrm{e}$ & 85.0 a & $55.25 \mathrm{a}$ \\
\hline
\end{tabular}

* Means within a column, row and their interactions followed with the same letters are not significantly different from each other according to Duncan's multiple range tests at $5 \%$ level.

Earlier attempts to eliminate some plant viruses using different electric current of 7 (46) and $15 \mathrm{~mA}$ (5) resulted in decreasing the level of virus titer in regenerated plantlets. Despite of the level and duration of electrotherapy, and plant genotype the efficiency of electrotherapy may be affected by structural differences between plant viruses as well as DMV has an isometric body. In addition to the limitations of conventional methods in virus elimination, their efficiency is also relatively low when compared with electrotherapy (32). Regenerated control explants without electrotherapy were tested positive for virus indicating that diminishing virus titer was due to electrotherapy and not to the in vitro regeneration. The electrotherapy technique described here was successful in eliminating dahlia mosaic virus. For production of virus-free plantlets, in addition to virus elimination, the efficiency of plant regeneration is also important because the adverse effects of electrotherapy may hamper the growth of dahlia plants (32). The regeneration rate of the treated plantlets was generally negatively affected by increasing the intensity of electrotherapy power, in such a way the highest regeneration was observed in treatment of $15 \mathrm{~mA}$ for $10 \mathrm{~min}$, followed by 25 $\mathrm{mA}$ for $10 \mathrm{~mA}$ and $35 \mathrm{~mA}$ for $10 \mathrm{~min}$. Treatment of $35 \mathrm{~mA}$ for $20 \mathrm{~min}$ led to the lowest regeneration percentage of $65 \%$ while showing the highest virus elimination rate of $85 \%$ (Tab. 3). Similar levels of regeneration have also been reported in earlier studies, including regeneration rates of 40 to $100 \%$
(5,32). There were no noticeable morphological differences among the regenerated plantlets (31). Electrotherapy is a simple and faster protocol of virus eradication, compared to conventional virus elimination techniques, without the need to use of any especial or expensive equipment (32). Based on our results, this method can be used as an effective technique for virus eliminating. Conditions of electrotherapy may differ depending on host-virus system, so it is important to determine the optimal electrotherapy treatment conditions for a desired host-virus system.Further studies are necessary to investigate the possible use of this protocol in other plant species especially vegetatively propagated ornamental plants.

\section{Chemotherapy}

The concentration of each antiviral influenced the number of the survived plants. There was a significant difference between the treatments in the number of the regenerated plants. Depending on the results showed in Tab.4 and 5 , the proportion of the obtained virus-free plants was increased by increasing the concentration of both antivirals. The highest concentration of acyclovir $(50 \mathrm{mg} / \mathrm{l})$ for 20 and 30 days were the best treatments as its highest effectiveness on elimination ability (90.67\%). On the other hand, depending on chemotherapy efficiency, $40 \mathrm{mg} / \mathrm{l}$ of acyclovir for 30 days (the longest incubation period) was the best treatment $(71.73 \%)$ as its highest effectiveness on elimination ability $(80 \%)$ and plantlet survival $(89.67 \%)$. The result was close to that of Dewanti et al. (5) who found that acyclovir produces $100 \%$ in vitro virus free plantlets. 
Table 4. Effects of different concentrations of acyclovir in period of times on the survival (\%) and DMV elimination (\%) of the in vitro initiated dahlia plantlets.

\begin{tabular}{|c|c|c|c|c|c|}
\hline $\begin{array}{l}\text { Acyclovir } \\
\text { Conc. }\end{array}$ & $\begin{array}{c}\text { Period of } \\
\text { Time (Day) }\end{array}$ & $\begin{array}{l}\text { Initiated } \\
\text { plantlets }\end{array}$ & $\begin{array}{c}\text { Plantlet Survival } \\
(\%)\end{array}$ & $\begin{array}{c}\text { DMV Elimination } \\
(\%)\end{array}$ & $\begin{array}{c}\text { Chemotherapy } \\
\text { Efficiency } \\
\%\end{array}$ \\
\hline 0.0 & - & 20 & $100 \mathrm{a}$ & $0.0 \mathrm{~h}$ & $0.0 \mathrm{~g}$ \\
\hline \multirow{2}{*}{10} & 20 & 20 & $100 \mathrm{a}$ & $0.0 \mathrm{~h}$ & $0.0 \mathrm{~g}$ \\
\hline & 30 & 20 & $100 \mathrm{a}$ & $0.0 \mathrm{~h}$ & $0.0 \mathrm{~g}$ \\
\hline \multirow{2}{*}{20} & 20 & 20 & $100 \mathrm{a}$ & $11.0 \mathrm{~g}$ & $11.0 \mathrm{f}$ \\
\hline & 30 & 20 & $100 \mathrm{a}$ & $14.33 \mathrm{f}$ & $14.33 \mathrm{f}$ \\
\hline \multirow{2}{*}{30} & 20 & 20 & $100 \mathrm{a}$ & $35.67 \mathrm{e}$ & 35.67 e \\
\hline & 30 & 20 & $94.33 \mathrm{~b}$ & $51.67 \mathrm{~d}$ & $48.74 \mathrm{c}$ \\
\hline \multirow{2}{*}{40} & 20 & 20 & $95.0 \mathrm{~b}$ & $65.0 \mathrm{c}$ & $61.75 \mathrm{~b}$ \\
\hline & 30 & 20 & $89.67 \mathrm{c}$ & 80.0 b & $71.73 \mathrm{a}$ \\
\hline \multirow{2}{*}{50} & 20 & 20 & $65.33 \mathrm{~d}$ & $90.0 \mathrm{a}$ & $58.79 \mathrm{~b}$ \\
\hline & 30 & 20 & $49.0 \mathrm{e}$ & $90.67 a$ & $44.42 \mathrm{~d}$ \\
\hline
\end{tabular}

-* Means within a column, row and their interactions followed with the same letters are not significantly different from each other according to Duncan's multiple range tests at $5 \%$ level.

Table 5 shows the effects of different concentration of salicylic acid and incubation period affecting the response of plantlets on DMV elimination. The therapy containing salicylic acid at $40 \mathrm{mg} / \mathrm{l}$ for 30 days was the best as its highest effectiveness on DMV elimination ability (100\%). At the same time, According to the therapy efficiency, the the longest incubation period (30 days) was the best treatment (chemotherapy efficiency= 49.21) as well as DMV elimination ability $(75.33 \%)$ and plant survival $(65.33 \%)$. The result was in agreement of that of Mahfouze et al. (16) and Mwangangi et al. (24). They found that the used chemicals are effective in viral elimination. The plants obtained from the control treatments $(0 \mathrm{mg} / \mathrm{l})$ resulted in $100 \%$ plant regeneration which all of them were positive to virus presence.

concentration of salicylic acid at $30 \mathrm{mg} / \mathrm{l}$ for

Table 5. Effects of different concentrations of Salicylic Acid in period of times on the survival $(\%)$ and DMV elimination (\%) of the in vitro initiated dahlia plantlets.

\begin{tabular}{|cccccc|}
\hline $\begin{array}{c}\text { Salicylic Acid } \\
\text { Conc. }\end{array}$ & $\begin{array}{c}\text { Period of } \\
\text { Time (Day) }\end{array}$ & $\begin{array}{c}\text { Initiated } \\
\text { plantlets }\end{array}$ & $\begin{array}{c}\text { Plantlet Survival } \\
(\%)\end{array}$ & $\begin{array}{c}\text { DMV Elimination } \\
(\%)\end{array}$ & $\begin{array}{c}\text { Chemotherapy } \\
\text { Efficiency } \\
\%\end{array}$ \\
\hline 0.0 & - & 20 & $100 \mathrm{a}$ & $0.0 \mathrm{~g}$ & $0.0 \mathrm{~g}$ \\
& 20 & 20 & $100 \mathrm{a}$ & $0.0 \mathrm{~g}$ & $0.0 \mathrm{~g}$ \\
& 30 & 20 & $100 \mathrm{a}$ & $0.0 \mathrm{~g}$ & $0.0 \mathrm{~g}$ \\
20 & 20 & 20 & $100 \mathrm{a}$ & $9.67 \mathrm{f}$ & $9.67 \mathrm{f}$ \\
& 30 & 20 & $89.67 \mathrm{~b}$ & $26.0 \mathrm{e}$ & $23.31 \mathrm{e}$ \\
30 & 20 & 20 & $75.33 \mathrm{c}$ & $59.33 \mathrm{~d}$ & $44.69 \mathrm{~b}$ \\
& 30 & 20 & $65.33 \mathrm{~d}$ & $75.33 \mathrm{c}$ & $49.21 \mathrm{a}$ \\
& 20 & 20 & $45.0 \mathrm{e}$ & $79.33 \mathrm{~b}$ & $35.69 \mathrm{c}$ \\
& 30 & 20 & $30.33 \mathrm{f}$ & $100 \mathrm{a}$ & $30.33 \mathrm{~d}$ \\
& 20 & 20 & $0.0 \mathrm{~g}$ & $0.0 \mathrm{~g}$ & $0.0 \mathrm{~g}$ \\
& 30 & 20 & $0.0 \mathrm{~g}$ & $0.0 \mathrm{~g}$ & $0.0 \mathrm{~g}$ \\
\hline
\end{tabular}

* Means within a column, row and their interactions followed with the same letters are not significantly different from each other according to Duncan's multiple range tests at $5 \%$ level. 
Effect of chemotherapy on DMV elimination from infected dahlia explants was influenced by the used antiviral compounds and the levels of concentration. Toxicity to plants and antiviral activity was more pronounced in higher concentrations of 50 and $30 \mathrm{mg} / \mathrm{l}$ of both acyclovir and salicylic acid respectively as evidenced by discoloration of leaves. This high toxicity resulted into high mortality of plants and then low survival rate of cultured explants. Increasing in acyclovir concentrations typically increases the effectiveness of virus elimination, but at higher concentrations especially at $50 \mathrm{mg} / \mathrm{l}$ slowed plant growth and phytotoxicity was evident. The required concentrations of many antivirals, that is necessary to inhibit virus multiplication, are very close to that point induce toxicity for host plants (26) thus at $40 \mathrm{mg} / \mathrm{l}$ and $30 \mathrm{mg} / \mathrm{l}$ survival rates decreased slowly but the number of the produced healthy plants was higher for both acyclovir and salicylic acid. In general, antivirals at effective low concentrations hinder virus replication. This concentration however needs to be below as well as acyclovir is not highly toxic to the plant at $40 \mathrm{mg} / \mathrm{l}$ but its phytotoxicity increased more and more at $50 \mathrm{mg} / \mathrm{l}$. Although salicylic acid had the lowest survival rates at $40 \mathrm{mg} / \mathrm{l}$, it resulted higher proportion of healthy plants while at $50 \mathrm{mg} / \mathrm{l}$ it induces high toxicity resulted into full mortality of in vitro cultured explants. Salicylic acid is a phenolic compound synthesized in plant in response to viral infection which is essential for local and systemic resistance $(13,44)$. It plays a vital role in signaling plant resistance to the infection while there is little information about its mechanism (43). Biosynthesis of salicylic acid is activated on recognition of viral effectors by $\mathrm{R}$ gene products. Activation of interaction induces several responses to inhibit virus multiplication at the site of infection $(3,7)$. It is also responsible for activation of systemic acquired resistance in distal tissues that reduces the effects of secondary attacks (2). The present study demonstrated that meristem culture, electrotherapy and chemotherapy are the techniques that can be used for in vitro elimination of DMV. Depending on the results and based on the efficiency of the therapies, chemotherapy using acyclovir $(40 \mathrm{mg} / 1$ for 30 days) is the best treatment can be used to produce in vitro DMV-free plants (efficiency of therapy $=72 \%$ ). Then, electrotherapy at $35 \mathrm{~mA}$ for $20 \mathrm{~min}$ gave good results (efficiency of therapy $=61.75 \%$ ) for this purpose. The used therapies can play a good role in virus elimination because they need the minimum period of time to regenerate fully developed healthy plants as long as 2-3 months.

\section{REFERENCES}

1. Agrios, G. N. 2005. Plant Pathology. Fifth Edition. Elsevier, Academic press. pp. 922

2. Alazem, M. and N.-S. Lin. 2015. Roles of plant hormones in the regulation of host-virus interactions. Molecular Plant Pathology, 16(5):529-540

3. Baebler, Š.; K. Witek; M. Petek; K. Stare; M. Tušek- Žnidarič; M. Pompe-Novak; J. Renaut; K. Szajko; D. Strzelczyk-Żyta; W. Marczewski; K. Morgiewicz; K. Gruden and J. Hennig. 2014. Salicylic acid is an indispensable component of the Ny-1 resistance-gene-mediated response against Potato virus $\mathrm{Y}$ infection in potato. Journal of Experimental Botany, 65:1095-1109

4. Badoni, A. and J.S. Chauhan. 2009. Effect of growth regulators on meristem-tip development and in vitro multiplication of potato cultivar 'Kufri Himalini'. Nature and Science Journal, 7:31-34

5. Bayati, S.H, M. Shams-Bakhsh, A. Moieni. 2011. Elimination of Grapevine virus A (GVA) by Cryotherapy and electrotherapy. Journal of Agricultural Scince Technology 13: 443-450

6. Dewanti, P.; L.I. Widuri; C. Ainiyati; P. Okviandari; Maisaro and B. Sugiharto. 2016. Elimination of SCMV (Sugarcane mozaik Virus) and rapid propagation of virus-free sugarcane (Saccharum officinarum L.) using somatic embryogenesis. Procedia Chemistry, 18:96-102

7. Dinesh-Kumar, S. P.; W. H. Tham, and B. J. Baker, 2000. Structure-function analysis of the tobacco mosaic virus resistance gene N. Proceedings of the National Academy of Sciences, 97, 14 789-14 794

8. Eid, S. and H.R. Pappu. 2014. Biological studies of three caulimoviruses associated with dahlia (Dahlia variabilis). Canadian Journal of Plant Pathology, 36(1):110-115 
9. García-Gonzáles, R.; K. Quiroz; B. Carrasco and P. Caligari. 2010. Plant tissue culture: current status, oppurtunities and challenges. Ciencia e investigación agraria: 37(3): 5-30

10. George, E. F.; M. A. Hall and G. JanDeklerk. 2008. Plant Propagation by Tissue Culture. $3^{\text {rd }}$ ed. Vol. 1. Pp.501

11. Hull, R. 2002. Matthew's Plant Virology. $4^{\text {th }}$ ed. Academic Press. Florida, USA. Pp: 1001 .

12. Ibrahim, M.A. and I.A. Daraj. 2015. Micropropagation of dahlia plants Dahlia variabilis Wild (Desf.). Effect of explant and plant growth regulators on shoot regeneration and growth. AAB Bioflux, 7(1):1-6

13. Loake, G. and M. Grant. 2007. Salicylic acid in plant defence-the players and protagonists. Current Opinion in Plant Biology, 10, 466-472

14. López-Delgado H.; M.E. Mora-Herrera; H.A. Zavaleta-Mancera; M. Cadena-Hinojosa, and I.M. Scott. 2004. Salicylic acid enhances heat tolerance and potato virus $\mathrm{X}$ (PVX) elimination during thermotherapy of potato microplants. American Journal of Potato Research, 81: 171-176

15. Lozoya-Saldana, H.F.; J. Abello and G. Garcia. 1996. Electrotherapy and shoot-tip culture eliminate Potato Virus $\mathrm{X}$ in potatoes. American Journal of Potato Research, 73:149154

16. Mahfouze, S.A.M; Kh.A. El-Dougdoug and E.K. Allam. 2010. Production of potato spindle tuber viroid-free potato plant materials in vitro. New York Science Journal, 3(8):6067

17. Mahmoud, S.Y.M.; M.H. Hosseny and M.H. Abdel-Ghaffar. 2009. Evaluation of some therapies to eliminate potato Y potyvirus from potato plants. International Journal of Virology, 5: 64-76

18. Mehmood, A.; A.H. Shah; M. Sajid and H. Ahmad. 2016. Investigation of $\mathrm{GA}_{3}$ effect on in vitro micropropagation of potato varieties. International Journal of Agronomical and Agricultural Research, 9(5): 21-30

19. Mervat, M.; M. El Far and A. Ashoub. 2009. Utility of thermotherapy and meristem tip for freeing sweet potato from viral infection. Australia Journal of Basic and Applied Science, 3:153-159
20. Meybodi, D.E.; J. Mozafari, N. Babaeiyan, and H. Rahimian. 2011. Application of electrotherapy for the elimination of potato Potyviruses. Journal of Agrcultural Sciences and Technology, 13:921-927

21. Milosevic S, A. A, Subotic; Bulajic I, Dekic S, Jevremovic A, Vucurovic and B. Krstic 2011. Elimination of TSWV from Impatiens hawkerii Bull and regeneration of virus-free plant. Electronic Journal Biotechnology, 14 (1).

22. Morel, G. and Martin, C. 1952. Guerison de dahlias atteints d'une maladie a virus. Comptes Rendus de l'Academie des Sciences, 235: 1324-1325

23. Mungai, G.; E. Ateka; A. Nyende and D. Miano. 2015. Evaluation of in vitro protocols for elimination of banana streak virus from tissue cultured explants in banana seedling production. Agricultural Sciences, 2(3):81-89

24. Mwangangi, M.; E. Ateka; A. Nyende and A. Kagundu. 2014. Elimination of cassava brown streak virus from infected cassava. Journal of Biology, Agriculture and Healthcare, 4(13):34-40

25. Naik, P. S. and J. L. Karihaloo. 2007. Micropropagation for Production of Quality Potato Seed in Asia-Pacific. Asia-pacific Consortium on Agricultural Biotechnology, New Delhi, India. pp: 54.

26. Nascimento, L.C.; G. Pio-Ribeiro; L. Willadino and G.P. Andrade. 2003. Stock indexing and potato virus $\mathrm{Y}$ elimination from potato plants cultivated in vitro. Scientia Agricola, 60(3):525-530

27. Nesi, B., D. Trinchello; S. Lazzereschi and A. Grassotti. 2009. Production of lily symptomless virus-free plants by shoot meristem tip culture and in vitro thermotherapy. Hort Science, 44(1): 217-219

28. Nerway, Zulaykha, A.A.; S. Rafail, Toma and A. Nabeel, Kassim. 2011. Identification and Purification of PVY and Micropropagation of Potato (Solanum tuberosum L.) Virus-Free Plants. MSc Thesis, College of Agriculture, University of Duhok

29. Nerway, Zulaykha, A.A.; Rafail, S. Toma and Nabeel, A. Kassim. 2012. Identification and Purification of Potato virus Y (PVY) in Duhok Governorate. Journal of University of Duhok, 15(1): 413-422 
30. Pappu, H.R.; S.D. Wyatt and K.L. Druffel. 2005. DMV: Molecular detection and distribution in dahlia in the US. HortScience, 40:697-699

31. Pazhouhande M. and J. Mozafari 2001. In Vitro Development of Potato Virus-Free Germplasm. Dissertation, Tarbiat Modarres University

32. Pazhohandeh, M., J. Mozafari, and A. Alizadeh, 2002. Electrotherapy a New Technique for Virus Eradication from Plants. In: Proceedings of the $15^{\text {th }}$ Iranian Plant Protection Congress. Razi University of Kermanshah, Iran, pp: 189-190

33. Sanjeev, S.; S. Balwinder; R. Gita, Z. Aijaz Asghar; H. Vipin; N. Avinash and V. Singh Gurdeep. 2007. Production of Indian citrus ring spot virus free plants of Kinnow employing chemotherapy coupled with shoot tip grafting. Journal of Central European Agriculture, 8:1-8

34. Sas, S. 2001. STAT User's Guide for Personal Computers, Release 6.12. SAS Institute Inc. Cary, NC, USA

35. Sastry K.S. and T. A. Zitter 2014. Plant Virus and Viroid Diseases in the Tropics. Springer, Volume 2: Epidemiology and Management, pp.489.

36. Schmidt, J.; E. Wilhem and V. A. Savangikar. 2004. Desease Detection and Elimination. Low cost option for tissue culture technology in developing countries. FAO and IAEA. pp. 55-61

37. Sharma, N.; P.P. Sahu; S. Puranik and M. Prasad. 2013. Recent advances in plant-virus interaction with emphasis on small interfering RNAs (siRNAs). Molecular Biotechnology, 55:63-77

38. Sedivá J., P. Novak; J. Laxa and J. Kanka. 2006. Micropropagation, detection and elimination of DMV in the Czech collection of Dahlia. Acta Horticulture, 725:495-498

39. Slevany, F.K.Y. 2008. Propagation of Potato (Solanum tuberosum L. cv. Desiree)
Through Tissue Culture. M.Sc. Thesis. College of Education, University of Duhok 40. Supaibulwattana, K., W. Kuntawunginn, S. Chaum, and C. Kirdmanee. 2011. Artemisinin accumulation and enhanced net photosynthetic rate in Qinghao Artemisia annua L.) hardened in vitro in enriched-CO2 photoautotrophic conditions. Plant Omics Journal, 4:75-81

41. Radwan, D.E.M.; K.A. Fayez; S.Y. Mahmoud; A. Hamad and G. Lu. 2006. Salicylic acid alleviates growth inhibition and oxidative stress caused by zucchini yellow mosaic virus infection in Cucurbita pepo leaves. Physiological and Molecular Plant Pathology, 69: 172-181

42. Richins, R.D. and R.J. Shepherd. 1983. Physical maps of the genomes of Dahlia mosaic virus and Mirabilis mosaic virus-Two members of the caulimovirus group. Virology, 124:208-214

43. Tian, M.; Z. Sasvari; P.A. Gonzalez; G. Friso; E. Rowland; X.M. Liu; K.J. van Wijk; P.D. Nagy and D.F. Klessig. 2015. Salicylic acid inhibits the replication of tomato bushy stunt virus by directly targeting a host component in the replication complex. Molecular Plant-Microbe Interactions, 28(4):379-386

44. Vlot, A.C.; D.A. Dempsey and D.F. Klessig. 2009. Salicylic Acid, a multifaceted hormone to combat disease. Annual Review of Phytopathology, 47:177-206

45. Xu, X. and S. Tiang. 2008. Salicylic acid alleviated pathogen-induced oxidative stress in harvested sweet cherry fruit. Postharvest Biology and Technology, 49:379-385

46. Yoon, J.; H. Wonseo; Y. Mee Choi and Y. Eun Park. 2003. Ribavirin, electric current, and shoot-tip culture to eliminate several potato viruses. Journal of Plant Biotechnology, 5(2):101-105

47. Kudělková, M.; R. Pavelková, and E. Ondruiiková. 2017. Virus elimination in peach using chemotherapy. Acta Horticulturae, 1155: 431-438. 